\title{
In-vitro fermentation characteristics and methane reduction potential of mustard cake (Brassica juncea L.)
}

\author{
S. M. Durge ${ }^{1,2,3}$, M. K. Tripathi ${ }^{1}$ and N. Dutta ${ }^{2}$
}

1. Division of Nutrition, Feed Resource and Product Technology, Central Institute for Research on Goats, Mathura - 281 122, Uttar Pradesh, India; 2. Division of Animal Nutrition, Indian Veterinary Research Institute, Bareilly - 243 122, Uttar Pradesh, India; 3. Department of Instructional Livestock Farm Complex, College of Veterinary and Animal Sciences, Udgir, Latur - 413 517, Maharashtra, India.

Corresponding author: S. M. Durge, e-mail: sdurge5@gmail.com, MKT: mktripathi@gmail.com, ND: dutta65@gmail.com

Received: 24-06-2016, Accepted: 07-09-2016, Published online: 26-10-2016

doi: 10.14202/vetworld.2016.1141-1146 How to cite this article: Durge SM, Tripathi MK, Dutta N (2016) In-vitro fermentation characteristics and methane reduction potential of mustard cake (Brassica juncea L.), Veterinary World, 9(10): 1141-1146.

\begin{abstract}
Aim: To assess the effect of mustard cake (Brassica juncea L.) levels in concentrate mixtures and in composite feed mixtures (CFMs) on in-vitro fermentation characteristics and methane production.

Materials and Methods: Five concentrate mixtures were prepared with containing 30\% oil cake, where linseed cake was replaced by mustard cake at the rate of $0 \%, 7.5 \%, 15.0 \%, 22.5 \%$, and $30 \%$ in concentrate mixture. Mustard cake contained glucosinolate $72.58 \mu \mathrm{mol} / \mathrm{g}$ oil free dry matter $(\mathrm{DM})$ and contents in diet were $0,5.4,10.9,16.3$, and $21.8 \mu \mathrm{mol} / \mathrm{g}$ of concentrate mixture, respectively. Concentrate mixture containing $15.0 \%$ mustard cake was found to produced minimum methane which was then used for the preparation of CFM containing $0 \%, 25 \%, 50 \%$, and $75 \%$ levels with gram straw.
\end{abstract}

Result: Increased levels of mustard cake in concentrate mixtures had a linear decrease $(\mathrm{p}<0.05)$ in the total gas production, and the $15 \%$ inclusion showed lowest methane concentration (quadratic, $\mathrm{p}<0.01$ ). The degradability of DM and organic matter $(\mathrm{OM})$ of concentrate mixtures did not change, however, $\mathrm{pH}$ and $\mathrm{NH}_{3}-\mathrm{N}$ concentrations of the fermentation medium showed linear $(\mathrm{p}<0.05)$ reductions with increased mustard cake levels. Increased levels of $15 \%$ mustard cake containing concentrate mixture in CFMs exhibited a trend $(\mathrm{p}=0.052)$ of increased gas production, whereas methane concentration in total gas, methane produced and degradability of DM and OM were also displayed a linear increase $(\mathrm{p}<0.05)$. However, the $\mathrm{pH}, \mathrm{NH}_{3}-\mathrm{N}$, and total volatile fatty acid levels decreased linearly $(\mathrm{p}<0.05)$ with increased levels of concentrate in CFMs.

Conclusion: Reduction in methane production was evidenced with the inclusion of mustard cake in concentrate mixture at $15 \%$ level, and the CFMs with $25 \%$ concentrate, which contained $15 \%$ mustard cake, exhibited an improved fermentation and reduced methane production.

Keywords: Brassica, glucosinolate, mustard cake, methane, rumen fermentation.

\section{Introduction}

Methane emitted by ruminants contributes sizably to the global methane emissions apart from representing a loss of feed energy, which can be used for productive purposes. Methane produced by ruminants contributes $20 \%$ of the total emissions through agricultural activities, in which each gram of methane production causes $55.65 \mathrm{~kJ}$ feed energy loss [1]. Ruminal methane emission is a synergy process between hydrogen producing and hydrogen utilizing resident microbes. The magnitude of methane emissions from rumen is affected by several factors, where diet and feeding, in particular, have great influence. Dietary modifications have been recommended as the viable strategies for decreasing methane production in rumen

Copyright: Durge, et al. Open Access. This article is distributed under the terms of the Creative Commons Attribution 4.0 International License (http://creativecommons.org/licenses/by/4.0/), which permits unrestricted use, distribution, and reproduction in any medium, provided you give appropriate credit to the original author(s) and the source, provide a link to the Creative Commons license, and indicate if changes were made. The Creative Commons Public Domain Dedication waiver (http://creativecommons.org/ publicdomain/zero/1.0/) applies to the data made available in this article, unless otherwise stated. ecosystem [2]. Dietary strategies, which do not have adverse effect on rumen ecology, could be exploited to reduce methane emission from ruminants. The inclusion of products and by-products of Brassica spp. were recommended in ruminant diets for methane mitigation [3]. Mustard cake, a by-product of oil extracting industries, is a cheap and easily available protein source for animal feeding in India [4]; this could be utilized in ruminant feeding as a protein supplement to reduced ruminal methane production.

The feeding cost accounts more than $70 \%$ of the total production cost of livestock, and therefore, the economization of the cost of feeding is a challenge for animal nutritionists. Protein supplements are the most costly feed ingredients used in animal feed. Alternate feed resources are added to the feed chain to increase the availability of feed resources and reduce the cost of feeding. Groundnut cake, soybean meal, linseed, and til cake are conventional protein supplements used in goat feeding. However, these are very costly, and availability for ruminant feeding is also limited. Mustard cake is widely available at cheaper prices but its utilization in goat feeding is limited because of 
its bitter taste and glucosinolate content [5]. Brassica forage and oil meals have showed a role in reducing methane production in the rumen $[3,6]$. Brassica forages may be a viable option for methane mitigation in pastoral animal production system [3], whereas Brassica oil meals can be adopted in pen feeding or supplementary feeding based livestock production for reducing methane production.

Therefore, keeping in view the potential availability, low cost and effect on rumen methane mitigation of Brassica products, the aim of this study was to assess the effect of mustard cake (Brassica juncea L.) levels in concentrate mixtures and in composite diets on in-vitro fermentation characteristics and methane reduction.

\section{Materials and Methods \\ Ethical approval}

The experimental protocol was duly cleared by the Institute Animal Ethic Committee.

\section{Animals, housing and feeding management}

Four adult Barbari male goats penned in a well-ventilated enclosure were fed on a composite diet comprising roughage (gram straw) to concentrate (linseed and mustard cakes $15.0 \%$ of each as protein supplements, barley 42.0, wheat bran 25.0, mineral mixture 2.0 , and common salt $1.0 \%$ ) in the ratio of 70:30. Three animals were used as donor of microbial inoculums during in-vitro study, and the nutrient requirement of donor animals was met as per recommendations [7].

\section{Feed formulations for in-vitro fermentation Experiment 1}

Five concentrate mixtures were formulated with mustard cake levels of 0 (MC-0), 7.5 (MC-7.5), 15.0 (MC-15.0), 22.5 (MC-22.5), and 30\% (MC-30.0) replacing $(\mathrm{w} / \mathrm{w})$ linseed cake at $0 \%, 25 \%, 50 \%, 75 \%$, and $100 \%$, respectively (Table- 1 ). The fermentation gas and methane production characteristics and the digestibility were determined. The concentrate mixture, which produced the lowest methane, was used in subsequent experiments.

\section{Experiment 2}

The concentrate mixture (MC-15.0) was incorporated at $0 \%, 25 \%, 50 \%$, and $75 \%$ levels in gram straw to formulate composite feed mixtures (CFM) of varying roughage and concentrate ratio, these CFMs have simulated the different feeding systems of goats.

\section{In-vitro fermentation}

The in-vitro fermentation studies were carried out in $100 \mathrm{ml}$ glass syringes. In brief, the concentrate mixtures and CFMs were ground to pass $1 \mathrm{~mm}$ screen. A $200 \mathrm{mg}$ homogenized sample was placed at the bottom of glass syringe, mixed with $30 \mathrm{ml}$ microbial inoculums and incubated at $39^{\circ} \mathrm{C}$ for $24 \mathrm{~h}$. The microbial inoculums used with slight modifications [8], inoculums contained distilled water $365 \mathrm{ml}$, buffer solution $183 \mathrm{ml}$, solution of macrominerals $183 \mathrm{ml}$ and microminerals $100 \mu \mathrm{l}$, strained rumen fluid $330 \mathrm{ml}$, resazurin $0.01 \mathrm{mg}$ and reducing solution $38.8 \mathrm{ml}$. The carbon dioxide was fluxed appropriately to maintain anaerobic conditions during fermentation. Each sample was incubated in triplicate with inoculums from three individual animals. Total gas production was measured by piston displacement method for $24 \mathrm{~h}$. The volume of gas formed was converted to $\mathrm{mmol}$ assuming $1 \mathrm{~mol}$ of gas was equivalent to $22.4 \mathrm{~L}$ of gas under the atmospheric pressure and temperature conditions of measurements. The methane content of the gas was analyzed, and fermentation metabolites were assessed in fermentation medium.

\section{Methane estimation}

The methane in fermented gas mixture was estimated using a gas chromatograph (GC) (PerkinElmerClarus-580, Singapore). A dual channel, dual column, microprocessor based GC was equipped with ECD and FDI detector and control module for temperature controls. Stainless steel column, which was suitable for methane analysis was used. The airtight sterilized syringes were used to withdraw the gas from the in-vitro syringes at the rubber outlet, which was injected in the GC and area of the graph plotted by output system was recorded for methane estimation.

Table-1: Composition of concentrated mixture.

\begin{tabular}{|c|c|c|c|c|c|}
\hline \multirow[t]{2}{*}{ Ingredients } & \multicolumn{5}{|c|}{ Concentrated mixtures ${ }^{a}$} \\
\hline & MC-O & MC-7.5 & MC-15 & MC-22.5 & MC-30 \\
\hline \multicolumn{6}{|c|}{ Ingredient composition $(\mathrm{g} / 100 \mathrm{~g})$} \\
\hline Barley & 42 & 42 & 42 & 42 & 42 \\
\hline Wheat bran & 25 & 25 & 25 & 25 & 25 \\
\hline Linseed cake & 30 & 22.5 & 15 & 7 & 0 \\
\hline Mustard cake & 0 & 7.5 & 15 & 22.5 & 30 \\
\hline Mineral mixture ${ }^{b}$ & 2 & 2 & 2 & 2 & 2 \\
\hline Common salt & 1 & 1 & 1 & 1 & 1 \\
\hline \multicolumn{6}{|c|}{ Chemical composition (g/100 g DM) } \\
\hline OM & 92.73 & 92.86 & 92.94 & 93.03 & 93.51 \\
\hline Crude protein & 20.10 & 19.97 & 19.86 & 19.97 & 20.05 \\
\hline Glucosinolate $(\mu \mathrm{mol} / \mathrm{g})$ & 0 & 5.44 & 10.89 & 16.33 & 21.77 \\
\hline
\end{tabular}

aMustard cake level in concentrate feed (g/100 g feed), bContained Ca 240, P 90, Mn 1.2, iron 6, Cu 1, Co 0.2, sodium chloride 300 , iodine 1 , and fluorine $<0.3 \mathrm{~g} / \mathrm{kg}$. OM=Organic matter, DM=Dry matter 


\section{Chemical analysis}

The dry matter (DM) was determined by drying at $70^{\circ} \mathrm{C}$ until constant weight. Organic matter $(\mathrm{OM})$ was estimated by ashing the dried samples at $450^{\circ} \mathrm{C}$ for $4 \mathrm{~h}$ as per AOAC [9]. The protein contents were determined by Kjeldahl technique $(\mathrm{N} \times 6.25)$ [9]. After $24 \mathrm{~h}$ incubation, $\mathrm{pH}$ of the fermentation medium was measured by the portable electronic $\mathrm{pH}$ meter (PCSTestr 35, Eutech Oakton Instruments, IL 60061, USA). Ammonia nitrogen was determined by the method of Weatherburn [10], and the total volatile fatty acids (TVFA) were estimated following the procedure of Barnett and Reid [11]. The glucosinolate content in mustard cake, concentrate mixtures, and CFMs was estimated [12] following Sephadex (DEAE-Sephadex A-25)-pyridine-acetate column procedure for glucosinolate purification [13].

\section{Statistical analysis}

The observations of gas and methane production, $\mathrm{DM}$ and $\mathrm{OM}$ digestibility, and fermentation characteristics were analyzed for statistically significance by analysis of variance procedure using a general linear mathematical model as: $\mathrm{Y}_{\mathrm{ijk}}=\mu+\mathrm{T}_{\mathrm{i}}+\mathrm{e}_{\mathrm{ij}}$, Where: $\mathrm{Y}_{\mathrm{ijk}}=$ Observation mean; $\mu=$ General mean, $T_{i}=$ Effect of $i^{\text {th }}$ treatment $(i=1,4$ or 5$), e_{i j}=$ Random error. The above model was also tested for level of significance using linear and quadratic effects against MC-0 in CFMs (SPSS base 16).

\section{Results}

\section{Experiment 1: Fermentation and methane produc- tion of concentrate mixtures}

Increased levels of mustard cake in concentrates reduced $(\mathrm{p}<0.05)$ total gas production, which ranged from 178 to $222 \mathrm{ml} / \mathrm{g}$ DM among different concentrates (Table-2). The concentration of methane in total gas ranged from $10.64 \%$ to $14.47 \%$, which was significantly $(\mathrm{p}<0.05)$ different among five concentrates. The concentrate mixture (MC-15) had the lowest methane concentration in total gas and showed a quadratic $(p<0.01)$ decrease in methane production. In spite of different methane concentrations in the total gas, methane production in terms of $\mathrm{L} / \mathrm{kg} \mathrm{DM}$ and $\mathrm{g} / \mathrm{kg}$ DM were similar among five concentrates. The protein content of mustard and linseed cake was identical. Mustard cake had glucosinolate $72.58 \mu \mathrm{mol} / \mathrm{g}$ oil free DM, which contributed glucosinolate 5.4, $10.9,16.3$, and $21.8 \mu \mathrm{mol} / \mathrm{g}$ concentrate, respectively, in MC-7.5, MC-15.0, MC-22.5, and MC-30 (Table-1). Inclusion of $\mathrm{MC}$ up to $30 \%$ in concentrate did not change the digestibility of DM and OM. However, the $\mathrm{pH}$ of the fermentation medium was reduced linearly $(p<0.05)$ with increased levels of mustard cake in concentrates. Mustard cake levels had a significant $(\mathrm{p}<0.05)$ influence on $\mathrm{NH}_{3}-\mathrm{N}$ concentration of fermentation medium. The MC- 0 concentrate mixture had the highest $(10.7 \mathrm{mg} / \mathrm{L}) \mathrm{NH}_{3}-\mathrm{N}$, and the lowest (4.4 mg/L) $\mathrm{NH}_{3}-\mathrm{N}$ was in MC-22.5 concentrate mixture (Table-2). Increased MC levels showed a linear $(p<0.001)$ decreased $\mathrm{NH}_{3}-\mathrm{N}$ concentrations of the fermentation mediums. Although MC inclusion levels did not show a significant change in TVFA concentrations, however a trend of decreased $(p=0.057)$ TVFA in fermentation medium was observed with increased $\mathrm{MC}$ levels in concentrates. The in-vitro fermentation of concentrates demonstrated that the $\mathrm{MC}$ at $15 \%$ level had the minimum methane concentration in fermentation gas and this level of MC also produced the lowest quantity of methane on each unit of concentrate incubated.

\section{Experiment 2: Fermentation and methane produc- tion of CFMs}

The total gas production among four CFMs exhibited a trend $(\mathrm{p}<0.052)$ of increased gas production with increased levels of concentrate mixture. However, increased concentrate levels in CFMs revealed linearly $(\mathrm{p}<0.001)$ increase $(\mathrm{L} / \mathrm{kg}$ or $\mathrm{g} / \mathrm{kg})$ in methane production up to $50 \%$ concentrate level (Table-3). Digestibility of DM and OM of CFMs increased $(p<0.05)$ with increased levels of concentrate in CFMs. Similarly, efficiency of methane production ( $\mathrm{ml}$ methane/g digestible OM) was reduced

Table-2: In-vitro fermentation gas and fermentation characteristics of the concentrate mixtures having graded levels of mustard cake (means of three observations).

\begin{tabular}{|c|c|c|c|c|c|c|c|c|c|}
\hline \multirow[t]{2}{*}{ Parameters } & \multicolumn{5}{|c|}{ Concentrate mixture $^{a}$} & \multirow[t]{2}{*}{ SEM } & \multicolumn{3}{|c|}{ Significance } \\
\hline & MC-O & MC-7.5 & MC-15.0 & MC-22.5 & MC-30.0 & & Treat & Linear & Quadratic \\
\hline \multicolumn{10}{|l|}{ Fermentation characteristics } \\
\hline $\begin{array}{l}\mathrm{pH} \\
\mathrm{NH}_{3}-\mathrm{N}(\mathrm{mg} / \mathrm{L})\end{array}$ & $\begin{array}{c}6.89 \\
10.78\end{array}$ & $\begin{array}{l}6.84 \\
8.97\end{array}$ & $\begin{array}{l}6.85 \\
5.95\end{array}$ & $\begin{array}{l}6.79 \\
4.45\end{array}$ & $\begin{array}{l}6.80 \\
4.75\end{array}$ & $\begin{array}{l}0.012 \\
0.779\end{array}$ & $\begin{array}{l}0.071 \\
0.007\end{array}$ & $\begin{array}{c}0.011 \\
<0.001\end{array}$ & $\begin{array}{l}0.537 \\
0.186\end{array}$ \\
\hline TVFA (mmole/L) & 23.3 & 21.3 & 18.6 & 11.6 & 11.3 & 2.294 & 0.355 & 0.057 & 0.958 \\
\hline \multicolumn{10}{|l|}{ Gas production characteristics } \\
\hline Gas (ml/g DM) & 195.4 & 222.0 & 199.5 & 177.9 & 179.5 & 5.834 & 0.077 & 0.045 & 0.238 \\
\hline Methane (\%) & 14.47 & 11.76 & 10.64 & 12.44 & 14.07 & 0.435 & 0.003 & 0.946 & $<0.001$ \\
\hline Methane (L/kg) & 37.14 & 37.20 & 31.07 & 33.82 & 38.44 & 1.320 & 0.419 & 0.935 & 0.131 \\
\hline Methane $(\mathrm{g} / \mathrm{kg})$ & 26.59 & 26.64 & 22.25 & 24.22 & 27.53 & 0.944 & 0.419 & 0.935 & 0.131 \\
\hline \multicolumn{10}{|l|}{ Digestibility } \\
\hline DM & 68.27 & 59.83 & 64.53 & 50.72 & 69.25 & 2.900 & 0.251 & 0.714 & 0.146 \\
\hline OM & 65.32 & 57.98 & 61.84 & 48.58 & 67.64 & 2.943 & 0.283 & 0.813 & 0.154 \\
\hline
\end{tabular}

aMustard cake level in concentrate feed $(\mathrm{g} / 100 \mathrm{~g}$ feed). OM=Organic matter, DM=Dry matter, TVFA=Total volatile fatty acid, SEM=Standard error of mean 
Table-3: In-vitro fermentation characteristics of gram straw based substrate with varying R:C (mean of three observations).

\begin{tabular}{|c|c|c|c|c|c|c|c|c|}
\hline \multirow[t]{2}{*}{ Parameters } & \multicolumn{4}{|c|}{ Complete feed mixture* } & \multirow[t]{2}{*}{ SEM } & \multicolumn{3}{|c|}{ Significance } \\
\hline & C-O & C-25 & C-50 & C-75 & & Treatment & Linear & Quadratic \\
\hline \multicolumn{9}{|c|}{ Fermentation characteristics } \\
\hline $\mathrm{pH}$ & 7.18 & 6.81 & 6.62 & 6.61 & 0.070 & 0.090 & $<0.001$ & $<0.001$ \\
\hline $\mathrm{NH}_{3}-\mathrm{N}(\mathrm{mg} / \mathrm{L})$ & 12.59 & 14.10 & 8.37 & 3.39 & 1.413 & $<0.001$ & $<0.001$ & 0.067 \\
\hline TVFA (mmole/L) & 26.0 & 30.0 & 19.3 & 12.0 & 2.424 & 0.012 & 0.024 & 0.593 \\
\hline \multicolumn{9}{|c|}{ Gas production characteristics } \\
\hline Gas (ml/gDM) & 86.2 & 132.0 & 117.9 & 134.5 & 7.974 & 0.091 & 0.052 & 0.262 \\
\hline Methane (\%) & 11.3 & 10.5 & 15.1 & 12.7 & 0.572 & $<0.001$ & $<0.001$ & 0.162 \\
\hline Methane (L/kg) & 20.39 & 23.65 & 32.01 & 29.17 & 1.476 & $<0.001$ & $<0.001$ & 0.043 \\
\hline Methane $(\mathrm{g} / \mathrm{kg})$ & 14.60 & 16.93 & 22.92 & 20.89 & 1.055 & $<0.001$ & $<0.001$ & 0.043 \\
\hline \multicolumn{9}{|l|}{ Digestibility } \\
\hline DM & 28.90 & 51.51 & 48.70 & 51.29 & 3.304 & 0.010 & 0.016 & 0.134 \\
\hline OM & 26.43 & 48.30 & 47.60 & 46.77 & 3.271 & 0.032 & 0.038 & 0.204 \\
\hline
\end{tabular}

*Level of concentrate (mustard cake $15 \mathrm{~g} / 100 \mathrm{~g})(\mathrm{g} / 100 \mathrm{~g})$ in gram straw based CFM. CFM=Composite feed mixture, $\mathrm{OM}=$ Organic matter, $\mathrm{DM}=$ Dry matter, TVFA=Total volatile fatty acid, SEM=Standard error of mean

$(\mathrm{p}<0.001)$ with increased concentrate levels in CFMs. The CFM with $25 \%$ concentrate (mustard cake $15 \mathrm{~g} / 100 \mathrm{~g}$ ) showed the lowest methane production and thus had the higher methane reduction efficiency. Increased level of concentrates in CFMs showed a linear $(\mathrm{p}<0.01)$ decrease in the $\mathrm{pH}$ values of the fermentation medium, while CFMs with $25 \%$ concentrates revealed a quadratic $(\mathrm{p}<0.001)$ decrease in the $\mathrm{pH}$ value. Moreover, increased concentrate levels in CFMs revealed a linear decrease in $\mathrm{NH}_{3}-\mathrm{N}$ concentration $(p<0.001)$ and TVFA levels $(p<0.05)$ in the fermentation medium. However, no significant differences were in $\mathrm{NH}_{3}-\mathrm{N}$ concentrations among CFMs with $0 \%, 25 \%$, and $50 \%$ concentrates. The TVFA levels of fermentation mediums did not demonstrate a definite trend.

\section{Discussion}

Decreased total gas production with increased mustard cake levels have corroborated favorably [14] and reported a low level of gas production in various rapeseed-mustard cakes with different levels of glucosinolates. However, an overall higher gas production in this study was due to higher fermentability of concentrate feeds in comparison to the fermentability of oil cakes alone. Although rapeseed-mustard cake contains good amount and quality of protein, glucosinolate content may limit its use in animal feeding. The glucosinolates themselves are biologically inactive molecules; however, glucosinolate degradation products are biologically active and known for their diversified biological effects. Negative effects of glucosinolate on animals are relative to its concentration in feed resource [5]. This study did not observe any adverse effect of mustard cake glucosinolate on DM digestibility, OM digestibility, and TVFA production because of low content in total diet [5]. Reduced levels of $\mathrm{NH}_{3}-\mathrm{N}$ together with TVFA in rumen fluid were indicative of improved microbial biomass synthesis [15], which in turn increased total gas production. There are three general approaches to mitigate methane emissions from ruminants. These include manipulation of rumen microbes, selection of animals (which naturally emit less methane) and nutritional management. Within nutritional interventions concentrates, oils, ionophores, nitrate, and sulfate have been examined and some of them are effective [16,17]. Brassica feeding in animals as a methane mitigant have been recommended [3]. The results of this study have indicated that concentrates with $15 \%$ mustard cake has a decreased rumen methane production. The varying levels of glucosinolate were not determined in this study. Increased methane production with higher level of concentrates in CFM might have accompanied by improved fermentation of feeds as Brassica products were more rapidly fermented [3] than the linseed cake/products, and mustard cake contained more proportion of rumen degradable proteins [18]. The product and by-products of Brassica (Brassica oleracea [Kale], Brassica campestris [turnip], Brassica napus [rape/swede], etc.) contained secondary plant metabolites including polyphenol oxidase, S-methyl cysteine sulfoxide, and glucosinolate [5], which might have altered gut bacterial communities particularly by the inclusion of glucosinolate-containing products in the diet [19]. Although there is no reported study on effects of any of these secondary plant metabolites on rumen methanogens, however a decreased methane production by $23 \%$ and $25 \%$, respectively, with rape and swede compared to ryegrass was reported in a pastoral based sheep production system [3]. In this study, methane yield increased with increased digestibility of CFM which was accompanied by higher levels of concentrates, whereas efficiency of methane production $(\mathrm{ml}$ methane/g digestible $\mathrm{OM})$ was decreased. Methanogenesis and methane production have a negative relationship with OM digestibility in sheep [3], where rape and swede grazing reduced methane emission by $25-43 \%$. Contrary to these, earlier studies $[19,20]$ did not find any relationship between digestibility and methane emissions. Although negative relationships between methane yield and 
digestibility, this phenomenon has suggested that the other factors have an overriding effect on methanogenesis in animals fed with Brassica feeds [3]. In this study, methane productions were not statistically different among the levels of mustard cake in concentrates; however, the methane production was gradually increased in concentrate mixtures with mustard cake levels of $22.5 \%$ and $30 \%$. The increased methane production in concentrate with $22.5 \%$ and $30 \%$ mustard cake levels could not be explained with present set of observations. Reduced $\mathrm{NH}_{3}-\mathrm{N}$ and TVFA have indicated a promoted microbial synthesis [15], which increased total gas production but methane production was not changed across the levels of mustard cakes. This might be due to no effect of mustard cake on methanogenic microorganisms. However, methane production in in-vitro system might have differed from in-vivo system in animal studies. Moreover, pattern of methane yield changed with substrate quality. Therefore, further studies are required for delineating the metabolic pathways that are involved in methane reduction, which is associated with mustard/Brassica product feeding. Linear decrease in $\mathrm{pH}$ of fermentation medium showed that the mustard cake inclusion have improved the soluble carbohydrate levels. However, $\mathrm{NH}_{3}-\mathrm{N}$ decreased with increased levels of mustard cake in spite of higher degradable protein content in mustard cake than in linseed cake. Decreased $\mathrm{NH}_{3}-\mathrm{N}$ along with reduced VFA is known for improved microbial protein synthesis in rumen. The rumen microbes utilize $\mathrm{NH}_{3}$ as nitrogen source and VFA as source of energy for their cell growth. Improved microbial protein synthesis with increased mustard cake levels have also been reported [6]. These findings are also in agreement with the observations, where no adverse effect of rapeseed meal feeding on rumen fermentation was reported [18] irrespective of their glucosinolate content. The increased production of propionate was reported [6] with the addition of rapeseed meal or rapeseed extract as source of glucosinolate, which reduced $\mathrm{pH}$ of fermentation medium, as more glucose was released from the hydrolysis of glucosinolate [5]. It is well established that increased levels of concentrates in composite diets have improved fermentability and fermentation metabolites level. In this study, no significant differences were revealed in total gas productions in CFMs with the $25-75 \%$ concentrate levels. Whereas, $\mathrm{pH}, \mathrm{NH}_{3}-\mathrm{N}$, and VFA decreased linearly with increased concentrate levels. The decline in rumen $\mathrm{pH}$ was associated with slow ammonia absorption in rumen and the small changes in rumen $\mathrm{pH}$ can have a marked influence on ammonia absorption from the rumen, through its effect on unionized ammonia concentrations have also been reported [21,22]. Results of the study revealed that rumen ammonia was either rapidly absorbed or incorporated in the microbial mass, thus did not corroborate with total-N-concentration in the rumen fluid.

\section{Conclusions}

The concentrate mixtures with 15\% mustard cake have contributed $10.9 \mu \mathrm{mol}$ glucosinolate/g DM, which resulted in decreased methane production without effecting fermentation metabolites. Inclusion of such concentrates at 25\% level in CFMs (R: C; 75:25) improved fermentation and reduced methane production efficiency ( $\mathrm{ml} / \mathrm{g}$ digestible $\mathrm{OM})$. Therefore, mustard cake could be used in ruminant feeding as a methane mitigant and could offer an economic option in feed formulation.

\section{Authors' Contributions}

SMD: Collection of ingredient, preparation of concentrate mixtures and composite feed mixtures, collection of rumen liquor, conduction of experiment, analysis of parameter, daily data recording and analysis, drafting and revision of the manuscript. MKT: Design of experiment, data analysis, critical manuscript writing and revision. ND: Provision of extra in-vitro assembly, technical support and manuscript reading. All authors read and approved the final manuscript.

\section{Acknowledgments}

The authors are thankful to the Director, Central Institute for Research on Goat (CIRG), Makhdoom for providing the necessary facilities to conduct the experiment. The research work was carried out in AICRP network project on methane mitigation by ICAR, New Delhi (Project grant no. ICAR \# 4(1)/2012-ASR-II). Authors also extend gratitude to Mr. D. L. Gupta and Mr. Dindayal for all extended help during work.

\section{Competing Interests}

The authors declare that they have no competing interests.

\section{References}

1. De Haas, Y., Windig, J.J., Calus, M.P.L., Dijkstra, J., de Haan, M., Bannink, A. and Veerkamp, R.F. (2012) Genetic parameters for predicted methane production and potential for reducing enteric emissions through genomic selection. J. Dairy Sci., 94: 6122-6164.

2. Cottle, D.J., Nolan, J.V. and Wiedemann, S.G. (2011) Ruminant enteric methane mitigation: A review. Anim. Prod. Sci., 51(6): 491-514.

3. Sun, X.Z., Waghorn, G.C., Hoskin, S.O., Harrison, S.J., Muetzel, S. and Pacheco, D. (2012) Methane emissions from sheep fed fresh brassicas (Brassica spp.) compared to perennial ryegrass (Loliumperenne). Anim. Feed Sci. Technol., 176: 107-116.

4. Swati, S.S. and Das, M. (2015) A brief overview: Present status on utilization of mustard oil and cake. Indian J. Tradit. Knowl., 14(2): 244-250.

5. Tripathi, M.K. and Mishra, A.S. (2007) Glucosinolates in animal nutrition: A review. Anim. Feed Sci. Technol., 132: 1-27.

6. Lee, K.Y., Kim, K.H., Baek, Y.C., Ok, J.U., Seol, Y.J., Han, K.J. and Oh, Y.K. (2013) Effects of mustard seeds and powder on in vitro ruminal fermentation characteristics and methane production. J. Anim. Sci. Technol., 55(1): 25-32. 
7. ICAR. (2013) Nutrient requirement of animals. Nutrient Requirements of Sheep, Goat and Rabbit. Vol. 2. Indian Council of Agricultural Research, New Delhi, India. p52.

8. Mould, F.L., Morgan, R., Kleim, K.E. and Krystallidou, E. (2005) A review and simplification of the in-vitro incubation medium. Anim. Nutr. Feed Technol., 123-124: 155-172.

9. AOAC. (2000) Official Method of Analysis. $17^{\text {th }}$ ed. Association of Official Analytical Chemist, Washington, DC.

10. Weatherburn, M.W. (1967) Estimation of ammonia nitrogen by colorimetric method. Anal. Chem., 39: 971-974.

11. Barnett, J.G.A. and Reid, R.L. (1957) Studies on production of volatile fatty acid from the grass by rumen liquor in an artificial rumen. J. Agric. Sci., 48: 315.

12. Nasirullah and Krishnamurthy, M.N. (1996) A method for estimating glucosinolates in mustard/rapeseed and cake. J. Food Sci. Technol., 33(6): 498-500.

13. Declereq, D.R. and Daun, J.K. (1989) Determination of total glucosinolates content in canola by reaction with thymol and sulfuric acid. J. Am. Oil Chem. Soc., 66: 788-791.

14. Mahima, V.K., Tomar, S.K., Roy, D. and Kumar, M. (2015) Effect of varying level of formaldehyde treatment of mustard oil cake on rumen fermentation, digestibility in wheat straw based total mixed diets in vitro. Vet. World, 8(4): 551.

15. Sirohi, S.S., Pandey, P. and Goel, N. (2012) Response of fumeric acid addition on methanogenesis, rumen fermentation and dry matter degradability in diets containing wheat straw and sorghum or berseem as roughage source. ISRN Vet. Sci., 2012: 496801

16. Kamra, D.N., Agarwal, N. and Chaudhary, L.C. (2015)
Manipulation of rumen microbial ecosystem of reducing enteric methane emission in livestock. In: Climate Change Impact on Livestock: Adaptation and Mitigation. Springer, India. p255-272.

17. Bodas, R., Prieto, N., Garcia-Gonzalz, R., Andres, S., Giraldez, F.J. and Lapez, S. (2012) Manipulation of rument fermentation and methane production with plant secondary metabolites. Anim. Feed Sci. Technol., 176(1): 78-93.

18. Durge, S.M., Tripathi, M.K., Tripathi, P., Dutta, N., Rout, P.K. and Chaudhary, U.B. (2014) Intake, nutrient utilization, rumen fermentation, microbial hydrolytic enzymes and hemato-biochemical attributes of lactating goats fed concentrate containing Brassica juncea oil meal. Small Rumin. Res., 121(2): 300-307.

19. Uyeno, Y., Katayama, S. and Nakamara, S. (2014) Changes in mouse gastrointestinal microbial ecology with ingestion of kale. Benificial Microbes. 5(3): 345-349.

20. Sun, X., Pacheco, D. and Luo, D. (2016) Forage brassica: A feed to mitigate enteric methane emission. Anim. Prod. Sci., 56(3): 451-456.

21. Hotshausen, L., Schartzkopf-Genscin, K.S. and Beauchemin, K.A. (2013) Short communication: Ruminal $\mathrm{pH}$ profile and feeding behavior of feedlot cattle transitioning from a high rorage to a high concentrate diet. Can. J. Anim. Sci., 93(4): 529-535.

22. Kmicikewyez, A.D., Harvatine, K.J. and Heinrichs, A.J. (2015) Effect of corn silage, particle size and supplementation hay and forage to concentrate ratio on rumen $\mathrm{pH}$, feed preference and milk fat profile of dairy cattle. J. Dairy Sci., 98(7): 4850-4868. 